\title{
PROFIL KOMUNIKASI MATEMATIKA TULIS SISWA DALAM PEMECAHAN MASALAH MATEMATIKA BERDASARKAN GAYA KOGNITIF FIELD DEPENDENT DAN FIELD INDEPENDENT
}

\author{
Rima Maisyah Ridwanah \\ Pendidikan Matematika, FMIPA, Universitas Negeri Surabaya, $e$-mail: rima.17030174070@mhs.unesa.ac.id \\ Masriyah \\ Pendidikan Matematika, FMIPA, Universitas Negeri Surabaya, $e$-mail: masriyah@unesa.ac.id
}

\begin{abstract}
Abstrak
Komunikasi berperan penting dalam pemecahan masalah matematika. Faktor yang mempengaruhi siswa dalam pemecahan masalah salah satu adalah gaya kognitif. Selain itu, gaya kognitif dapat mempengaruhi cara siswa untuk memproses informasi apabila ketika mengomunikasikan ide pemecahan masalah. Tujuan dari penelitian ini untuk mendeskripsikan profil komunikasi matematika tulis siswa dalam pemecahan masalah matematika berdasarkan gaya kognitif field dependent (FD) dan field independent (FI) yang dimiliki siswa. Penelitian ini adalah penelitian deskriptif dengan pendekatan kualitatif yang dilaksanakan di UPT SMP Negeri 5 Gresik. Penelitian ini menggunakan instrument Tes Kemampuan Matematika (TKM), Tes GEFT, dan Tes Komunikasi Matematika Tulis (TKMT). TKM untuk memilih subjek penelitian sehingga setiap subjek penelitian memiliki kemampuan matematika tinggi yang setara. Tes GEFT untuk mengelompokkan siswa dengan gaya kognitif FD dan FI. Sedangkan TKMT untuk mendeskripsikan profil komunikasi matematika tulis siswa dalam pemecahan masalah. Teknik analisis data terdiri dari analisis tes TKM, GEFT, dan TKMT. Ada dua subjek dalam penelitian ini yaitu, satu subjek gaya kognitif field dependent (FD) dan satu subjek gaya kognitif field independent (FI). Pada penelitian ini diperoleh hasil dimana gaya kognitif FI memiliki komunikasi matematika tulis dengan uraian: subjek SFI dalam memahami masalah menuliskan hal-hal yang diketahui serta ditanyakan secara akurat, lengkap, dan lancar. Selanjutnya, subjek SFI membuat rencana penyelesaian dengan menuliskan strategi pemecahan masalah, istilah/notasi, dan membuat gambar atau sketsa secara akurat, lengkap, dan lancar. Dalam tahap melaksanakan rencana penyelesaian, subjek SFI menuliskan tahap-tahap perhitungan dengan akurat, lengkap, dan lancar. Selanjutnya pada tahap memeriksa kembali, kesimpulan dituliskan secara akurat, lengkap, dan lancar oleh subjek SFI. Di sisi lain subjek dengan gaya kognitif FD memiliki komunikasi matematika tulis dengan uraian: Subjek SFD dalam memahami masalah menuliskan hal-hal yang diketahui serta ditanyakan secara akurat, lengkap, dan tidak lancar. Selanjutnya, subjek SFD membuat rencana penyelesaian dengan menuliskan strategi pemecahan masalah secara tidak akurat, tidak lengkap, dan tidak lancar. Sedangkan dalam menuliskan istilah atau notasi dan membuat gambar atau sketsa secara akurat, lengkap, dan lancar. Dalam tahap melaksanakan rencana penyelesaian, subjek SFD menuliskan tahap-tahap perhitungan dengan tidak akurat, lengkap, dan tidak lancar. Selanjutnya pada tahap memeriksa kembali, kesimpulan dituliskan secara tidak akurat, tidak lengkap, dan tidak lancar oleh subjek SFD. Berdasarkan deskripsi dan hasil analisis dalam penelitian ini, menunjukkan bahwa gaya kognitif field dependent dan field independent dapat mempengaruhi komunikasi tulis siswa dalam pemecahan masalah. Oleh karena itu, penting bagi guru dan siswa untuk mengetahui komunikasi matematika tulis agar dapat meningkatkan kemampuan dan pemahaman dalam pemecahan masalah.
\end{abstract}

Kata Kunci: komunikasi matematika, pemecahan masalah, gaya kognitif field dependent dan field independent.

\begin{abstract}
Communication plays an important role in solving math problems. To communicate problem solving well, good mathematical communication is needed. This study aimed to describe students' written mathematics communication profile in solving mathematics problems based on the field dependent and field independent cognitive styles. The instruments used in this study were the Mathematics Ability Test (TKM), the GEFT Test, and the Written Mathematics Communication Test (TKMT). This study's subjects were two students, one student with a field dependent cognitive style and one student with a field independent cognitive style. The results showed that the subject with the field independent cognitive style had written mathematics communication with the following details: in the step of understanding the problem, the SFI subject wrote what was known and asked accurate, complete, and smooth. In the step of making a completion plan, the SFI subject wrote an accurate, complete, and smooth completion strategy, terms/notations, and
\end{abstract}


drawings/sketches. In the step of carrying out the completion plan, the SFI subject wrote the calculation steps accurate, complete, and smooth. Furthermore, in the step of checking again, the SFI subject wrote conclusions accurate, complete, and smooth. While the subject with the field dependent cognitive style has written mathematical communication with the following details: in the step of understanding the problem, the SFD subject wrote things that are known and asked accurate, complete, and not smooth. In the step of making a settlement plan, the SFD subject wrote inaccurate, incomplete, and not smooth resolution strategies. Meanwhile, in writing the terms/notations and pictures/sketches made, they are accurate, complete, and fluent. In the step of implementing the completion plan, the SFD subject wrote inaccurate, incomplete, and not smooth calculation steps. Furthermore, in the re-examination step, the SFD subject wrote inaccurate, incomplete, and not smooth conclusions.

Keywords: mathematics communication, problem solving, field dependent and field independent cognitive style.

\section{PENDAHULUAN}

Komunikasi merupakan bagian penting dalam kegiatan manusia. Sejak lahir di dunia manusia telah melakukan tindakan komunikasi. Kemampuan berkomunikasi dengan baik akan berpengaruh terhadap interaksi seseorang di lingkungannya. Standar isi kurikulum 2013 sesuai Permendikbud Nomor 21 tahun 2016 menjelaskan bahwa kompetensi yang ditagih dalam kegiatan belajar mengajar meliputi tiga hal yakni pengetahuan, sikap, dan keterampilan. Salah satu kemampuan yang harus dimiliki siswa dalam kegiatan belajar mengajar yaitu menguasai keterampilan komunikasi dengan baik. Sehubungan dengan itu, kurikulum 2013 juga menjelaskan dalam menghadapi tantangan atau masalah lainnya di masa globalisasi mendatang membutuhkan beberapa kemampuan, salah satunya yaitu komunikasi.

Satriawati (2006) memberi pengertian mengenai komunikasi yakni suatu cara menyalurkan ide atau gagasan dan memperdalam pemahaman yang selanjutnya direfleksikan, diperbaiki, didiskusikan, dan diubah. Proses komunikasi dapat membantu siswa membangun ide-ide atau makna. Menurut NCTM (2000: 268), komunikasi merupakan fitur atau ciri utama ketika siswa mampu mengekspresikan hasil pemikirannya baik tertulis maupun lisan. Lebih lanjut Dewi (2009) mengemukakan bahwa komunikasi adalah suatu proses dimana seseorang menggunakan isyarat secara natural ataupun universal, simbol-simbol secara verbal ataupun nonverbal, sengaja atau tidak sengaja tetapi mempunyai maksud, dan menyampaikan makna kepada orang lain agar menimbulkan perubahan. Sehingga berdasarkan berbagai pendapat tersebut maka peneliti memaknai komunikasi merupakan proses penyampaian pesan atau informasi antara manusia agar orang lain memahami pesan atau informasi tersebut.

Salah satu hal yang perlu diajarkan kepada siswa yaitu bagaimana agar siswa mampu mengungkapkan pemikirannya, sehingga siswa dapat lebih siap bersosialisasi dalam masyarakat jika kemampuan berkomunikasinya baik. Pada dunia pendidikan, komunikasi berpengaruh dalam pembelajaran matematika. Pelajaran matematika menjadi alat berfikir yang membantu siswa untuk mengembangkan pola. Selain itu, sebagai alat untuk menyelesaikan masalah dan menarik kesimpulan, serta mengomunikasikan gagasan atau pikiran secara singkat, tepat dan jelas.

Berdasarkan Lampiran 3 Permendikbud Nomor 58 tahun 2014 salah satu tujuan kurikulum 2013 dalam pembelajaran matematika yaitu siswa dapat mengomunikasikan ide, penalaran, dan dapat menyusun pembuktian matematika dengan kalimat yang lengkap dan menggunakan simbol, tabel, diagram, atau media lainnya untuk memperjelas suatu masalah. Komunikasi matematika menurut NCTM (2000) yaitu kemampuan siswa ketika menjelaskan algoritma sekaligus cara yang khas dalam pemecahan masalah, kemampuan siswa dalam mengonstruksikan dan menjelaskan tentang fenomena nyata baik secara grafis, kalimat, persamaan, dan tabel atau kemampuan siswa memberikan dugaan tentang gambar dalam geometri.

Siswa dikatakan memiliki kemampuan komunikasi matematika jika mampu mengomunikasikan sebuah gagasan melalui lisan dan tulis baik berupa simbol, catatan, grafik, diagram, tabel atau karya visual untuk menggambarkan sebuah masalah. Sehingga siswa akan terbiasa mengomunikasikan apa yang dipahami dalam pikirannya. Komunikasi matematika menjadi kemampuan dasar yang harus dikembangkan dalam pembelajaran matematika. Kebanyakan komunikasi matematika siswa terabaikan karena guru hanya fokus dalam pencapaian kurikulum dan hanya mementingkan hasil dari pada prosesnya. Sehingga siswa akan terbiasa mengomunikasikan apa yang dipahami dalam pikirannya. Menurut New York State Board (2005) menjelaskan komunikasi matematika siswa dalam pembelajaran matematika akan memperoleh suatu pemahaman dan memiliki ingatan yang baik tentang pengetahuan matematika ketika siswa memberi alasan matematika, melakukan pemecahan masalah, pembuktian matematika, partisipasi dalam wacana matematika (komunikasi matematika), membuat koneksi matematika dan model 
matematika yang mewakili gagasan dalam berbagai cara. Dengan demikian, siswa harus diarahkan oleh guru untuk mengkomunikasikan gagasan matematikanya. Margarani (2016) berpendapat bahwa komunikasi matematika adalah kemampuan seseorang dalam mengutarakan gagasan matematika kepada orang lain secara jelas dan mudah dipahami. Diperlukan indikator atau petunjuk untuk mengetahui komunikasi matematika agar dapat menentukan apakah informasi yang diberikan akurat, lengkap, dan lancar.

Terdapat dua komunikasi matematika yang diungkapkan Dewi (2009, 21) yaitu komunikasi matematika lisan dan komunikasi matematika tulis. Komunikasi matematika lisan merupakan proses mengemukakan ide atau gagasan matematika melalui katakata, sedangkan komunikasi matematika tulis adalah proses penyampaian gagasan matematika yang diwujudkan melalui tulisan. Adapun perbedaan komunikasi tulis dan komunikasi lisan, salah satunya yakni apabila seseorang melakukan ketidaktepatan dalam berbicara. Tindakan tersebut merupakan hal biasa dalam bahasa lisan. Akan tetapi apabila dalam komunikasi tulis terjadi ketidaktepatan maka tulisan tersebut dianggap kurang baik. Selain itu, dalam komunikasi lisan, seseorang dapat memilih kata yang akan diucapkan secara tepat. Sedangkan pada komunikasi tulis, seseorang harus melakukan beberapa pertimbangan atau melakukan koreksi terhadap kata yang digunakan untuk menyusun kalimat.

Berdasarkan informasi dari salah satu guru matematika UPT SMP negeri 5 Gresik bahwa ketika proses pembelajaran di kelas hanya ada beberapa siswa yang aktif bertanya jika mengalami kesulitan dalam mengerjakan soal dan memberi tanggapan dari pertanyaan guru. Ketika peneliti melakukan PLP di sekolah tersebut, peneliti mengetahui bahwa kebanyakan siswa masih kurang tepat dalam mengungkapkan ide-ide matematika secara tertulis dan lebih menggunakan cara yang singkat tanpa memperhatikan kelengkapan simbol-simbol matematika. Peneliti juga melihat bahwa siswa merasa kebingungan apabila diberi soal yang berbeda dengan contoh soal yang sudah diberikan sebelumnya karena siswa mempelajari matematika hanya dengan menghafal rumus dan cara tanpa memahaminya. Hal tersebut mengakibatkan kurangnya kemampuan komunikasi siswa khususnya kemampuan dalam komunikasi tulis.

Dalam penelitian ini, komunikasi yang dibahas adalah komunikasi matematika tulis. Martini (2015:21) mengatakan bahwa dalam pembelajaran matematika, kegiatan komunikasi matematika tertulis penting dilakukan. Sejalan dengan itu, komunikasi matematika tulis bisa dalam bentuk gambar, kata-kata, tabel, dan lainnya yang merefleksikan proses berpikir siswa (Mahmudi, 2009:3). Menurut American Education
Reaches Out (AERO, 2011) kemampuan dalam mengungkapkan ide dan menjelaskan suatu penyelesaian secara tertulis perlu diperhatikan dalam kurikulum matematika. Komunikasi matematika tulis dalam penelitian ini adalah proses penyampaian pesan atau informasi yang jelas dan mudah dipahami oleh orang lain dalam bentuk tulis.

Scheidear \& Saunder (dalam Dewi, 2009) menjelaskan keterkaitan antara komunikasi matematika dengan pemecahan masalah, siswa menyelesaikan masalah yang diberikan kemudian mengomunikasikan hasil pemikirannya kepada orang lain. Jadi untuk mengomunikasikan pemecahan masalah dengan baik, maka diperlukan komunikasi matematika yang baik. Pemecahan masalah menurut Isroil, dkk. (2017) adalah upaya untuk mendapatkan jawaban atau solusi dari masalah yang disampaikan dengan memanfaatkan konsep atau pengetahuan matematika yang telah dipelajari sebelumnya. Menurut Hudojo (2005) pemecahan masalah adalah suatu hal yang paling essensial dalam pembelajaran matematika dikarenakan siswa akan lebih terampil dalam menyeleksi informasi yang relevan yang selanjutnya menganalisis dan kemudian meneliti hasilnya, lebih dari itu kepuasan intelektual akan tercipta dari dalam dan dapat meningkatkan potensi intelektual siswa.

Aktivitas atau upaya yang dilakukan siswa dalam menyelesaikan suatu soal matematika yang tidak bisa diselesaikan dengan prosedur rutin disebut pemecahan masalah. Terdapat 4 langkah pemecahan masalah menurut Polya (1973), yaitu: (1) Understanding the problem/memahami masalah, (2) Devising a plane/membuat rencana penyelesaian, (3) Carrying out the plane/menyelesaikan rencana penyelesain, dan (4) Looking back/memeriksa kembali. Siswono (2008: 35) menjelaskan bahwa pemecahan masalah merupakan suatu proses atau cara individu untuk merespon atau mengatasi suatu kendala ketika terdapat jawaban atau metode jawaban tidak jelas. Dari beberapa pendapat diatas maka menurut peneliti pemecahan masalah matematika adalah proses menemukan solusi untuk mengatasi masalah matematika dalam mencapai tujuan dengan menggunakan pengetahuan dan keterampilan yang dimilikinya. Adapun indikator komunikasi matematika tulis dalam pemecahan masalah yang diteliti dalam penelitian ini adalah keakuratan, kelengkapan, dan kelancaran yang diadaptasi dari penelitian Dewi (2009).

Pada kegiatan pembelajaran matematika, siswa banyak melakukan kegiatan seperti menginterpretasi, menyimak, menelaah, dan mengevaluasi gagasan, simbol, istilah, serta informasi matematika lainnya. Setiap siswa pasti memiliki perbedaan dalam cara mengomunikasikan informasi yang didapat selama proses pembelajaran matematika. Perbedaan tersebut memperlihatkan suatu ciri khas atau 
karakteristik. Menurut Rahyubi (2012) untuk meraih tujuan yang hendak dicapai dalam suatu pembelajaran, guru harus mempertimbangkan ciri khas siswa yang beragam dan unik. Hal tersebut difokuskan agar dapat membantu guru dan siswa dalam perbaikan dan pengembangan pembelajaran matematika. Terdapat beberapa faktor yang menyebabkan munculnya karakteristik siswa, salah satunya adalah gaya kognitif. Pratiwi, D. D. (2013) mengemukakan bahwa salah satu hal yang mempengaruhi kemampuan komunikasi matematika tulis siswa dalam pemecahan masalah adalah gaya kognitif. Selain itu, siswa dalam memecahkan masalah juga memiliki cara yang khas yang tidak lepas dari bagaimana cara belajarnya. Cara siswa yang khas dalam belajar baik berhubungan dengan cara penerimaan dan pengetahuan informasi, tindakan terhadap informasi, ataupun kebiasaan yang berhubungan dengan lingkungan belajar disebut gaya kognitif (Uno, 2008). Dalam hal ini, Susan \& Collinson (2005) berpendapat bahwa strategi dalam memecahkan masalah dipengaruhi oleh gaya kognitif. Oleh karena itu, gaya kognitif dapat mempengaruhi cara siswa untuk memproses informasi apabila ketika mengomunikasikan ide pemecahan masalah.

Permasalahan yang terjadi adalah guru masih memandang bahwa siswa mempunyai kemampuan yang sama dalam memecahkan masalah dan menerima pelajaran matematika. Dalam pembelajaran matematika guru belum memperhatikan gaya kognitif siswa. Guru hanya menyesuaikan metode, strategi, ataupun model pembelajaran dengan keadaan sekolah, sehingga meskipun telah menggunakan metode, strategi, ataupun model pembelajaran yang dianggap sudah tepat, siswa masih mengalami kendala dalam menguasai materi yang menyebabkan kurangnya komunikasi matematika siswa serta prestasi belajarnya. Rostampour \& Niroomand (2014:52) mengatakan bahwa "guru harus memahami perbedaan individu sebagai pertimbangan sehingga dapat mengadopsi dan menerapkan metode pembelajaran yang sesuai dengan gaya kognitif yang dimiliki siswa".

Menurut Witkin (1977) gaya kognitif sebagai respon yang dimunculkan oleh seseorang yang berhubungan dengan perbedaan pendekatan karakteristik dari persepsi maupun intelektual seseorang yang membawanya untuk merespon situasi yang dihadapi. Gaya kognitif diklasifikasikan menjadi berbagai cara, satu diantaranya yaitu melakukan identifikasi dan mengelompokkan sesuai kontinum global analitik (Witkin, 1977). Berlandaskan hal tersebut, gaya kognitif dibagi menjadi gaya kognitif Field Dependent (FD) dan gaya kognitif Field Independent (FI).

Dalam penelitian ini, gaya kognitif yang digunakan adalah gaya kognitif FI dan FD. Wooldridge (2006) berpendapat bahwa individu yang mempunyai gaya kognitif FI ketika menanggapi stimulus mereka cenderung menggunakan persepsi yang dimilikinya sendiri dan lebih analisis. Individu yang memiliki gaya kognitif FD dalam menanggapi stimulus mereka cenderung memandang suatu pola menjadi suatu keseluruhan atau global dan cenderung menggunakan isyarat lingkungan menjadi pedoman dalam persepsinya, serta tidak meninggalkan bagian-bagiannya. individu yang memiliki gaya kognitif FI dapat bekerja lebih baik apabila diberi kebebasan dalam mengerjakan tugas atau menyelesaikan suatu soal, maka. Sebaliknya individu yang memiliki gaya kognitif FD dapat bekerja lebih baik apabila diberikan petunjuk atau bimbingan lebih. Sedangkan menurut penelitian Arifin et al. (2015) menyimpulkan "siswa dengan gaya kognitif FI memiliki respon pemecahan masalah matematika yang lebih kompleks dibandingkan dengan siswa yang gaya kognitif FD yang cara pengerjaannya lebih umum". Achir, dkk (2017) menyimpulkan bahwa siswa dengan gaya kognitif FD mempunyai kemampuan komunikasi matematika tulis termasuk kelompok rendah-sedang, sedangkan siswa yang memiliki gaya kognitif FI memiliki kemampuan komunikasi matematika tulis termasuk kelompok tinggisangat tinggi.

Adapun penelitian sebelumya yang relevan dengan penelitian ini adalah penelitian yang dilakukan oleh Dewi (2009) yang berjudul "Profil Komunozdeikasi Matematika Siswa Calon Guru Ditinjau dari Perbedaan Jenis Kelamin”. Penelitian tersebut hanya menggunakan tiga langkah pertama pemecahan masalah Polya, yaitu memahami masalah, merencanakan pemecahan masalah, dam melaksanakan pemecahan masalah. Sedangkan dalam penelitian ini menggunakan empat langkah pemecahan masalah Polya, peneliti menggunakan empat langkah pemecahan masalah Polya karena langkah keempat bertujuan untuk mengecek atas apa yang telah dilakukan mulai dari langkah pertama sampai langkah ketiga. Penelitian Dewi (2009) ditinjau dari perbedaan jender, sedangkan pada penelitian ini ditijau dari gaya kognitif field dependent dan field independent.

Dari uraian diatas, maka dimungkinkan adanya perbedaan komunikasi matematika dalam menyelesaikan soal dengan gaya kognitif masing-masing siswa. Dari paparan diatas, peneliti tertarik untuk melaksanakan penelitian dengan judul "Profil Komunikasi Matematika Tulis Siswa dalam Pemecahan Masalah Matematika Berdasarkan Gaya Kognitif Field Dependent dan Field Independent"

\section{METODE}

Penelitian ini merupakan penelitian deskriptif melalui pendekatan kualitatif karena tujuan pada penelitian ini adalah memberikan gambaran atau mendeskripsikan tentang suatu keadaan yang objektif. Peneliti menggunakan data kualitatif dengan maksud atau tujuan mendeskripsikan 
profil komunikasi matematika tulis siswa dalam pemecahan masalah matematika berdasarkan gaya kognitif FD dan FI. Sumber data dari penelitian ini adalah 32 siswa kelas IX UPT SMP Negeri 5 Gresik pada semester ganjil tahun akademik 2020/2021, menggunakan angket yang disajikan dalam google form, dilanjutkan dengan memberikan tes komunikasi matematika tulis kepada siswa yang telah terpilih menjadi subjek penelitian.

Pada penelitian ini, tes yang digunakan yaitu Tes Kemampuan Matematika (TKM), tes GEFT, dan Tes Komunikasi Matematika Tulis (TKMT). Agar kualitas tes baik maka tes telah diuji coba keterbacaannya. TKM digunakan untuk memilih subjek penelitian sehingga setiap subjek penelitian memiliki kemampuan matematika tinggi yang setara. Ritonga (2018) menjelaskan bahwa kemampuan komunikasi matematika siswa yang mempunyai kemampuan matematika tinggi dapat dikategorikan baik. Siswa yang mempunyai kemampuan matematika tinggi merupakan siswa yang memperoleh skor tes kemampuan matematika 85-100, siswa yang mempunyai kemampuan matematika sedang adalah siswa dengan skor tes kemampuan matematika 70-84, dan siswa yang mempunyai kemampuan matematika rendah adalah siswa yang memperoleh skor tes kemampuan matematika 0-69. Soal yang digunakan dalam TKM diadaptasi dari soal Ujian Nasional dengan bentuk soal uraian. Soal Ujian Nasional dipilih karena merupakan soal standar nasional yang sudah divalidasi dari tingkat pemerintahan pusat. Tes GEFT digunakan untuk mengelompokkan siswa dengan gaya kognitif FD dan FI. Tes ini merupakan tes preseptual yang dikembangkan dari EFT oleh Herman A. Witkin dkk. Hal ini dilakukan dengan memberikan tes GEFT kepada siswa yang memiliki kemampuan matematika tinggi. Sedangkan TKMT berguna untuk mendeskripsikan profil komunikasi matematika tulis siswa dalam pemecahan masalah. TKMT diberikan kepada dua subjek yang terpilih. Selanjutnya, setiap subjek diminta untuk menyelesaikan secara individu dalam batas waktu 25 menit. Dalam penelitian ini, aspek yang dinilai adalah keakuratan, kelengkapan, dan kelancaran komunikasi matematika tulis siswa dalam pemecahan masalah dengan menggunakan indikator-indikator yang diadaptasi dari Dewi (2009).

Tabel 1 Indikator Komunikasi Matematika Tulis Siswa dalam Pemecahan Masalah Matematika

\begin{tabular}{|c|c|c|c|}
\hline Aapek & $\begin{array}{c}\text { Langkah } \\
\text { Penyelesaian }\end{array}$ & Informasi yang Disampaikan & Kode \\
\hline \multirow{3}{*}{ Keakuratan } & $\begin{array}{l}\text { Memahami } \\
\text { Masalah }\end{array}$ & $\begin{array}{l}\text { Menuliskan yang hal-hal yang } \\
\text { diketahui dan ditanyakan dengan } \\
\text { benar. }\end{array}$ & TM1 \\
\hline & \multirow{2}{*}{$\begin{array}{l}\text { Membuat } \\
\text { Rencana } \\
\text { Penyelesaian }\end{array}$} & $\begin{array}{l}\text { Menuliskan strategi penyelesaian } \\
\text { dengan benar. }\end{array}$ & TB1 \\
\hline & & $\begin{array}{l}\text { Menuliskan istilah/notasi } \\
\text { matematika dengan benar menurut } \\
\text { kaidah matematika. }\end{array}$ & TB2 \\
\hline
\end{tabular}

\begin{tabular}{|c|c|c|c|}
\hline Aapek & \begin{tabular}{|c|} 
Langkah \\
Penyelesaian
\end{tabular} & Informasi yang Disampaikan & Kode \\
\hline & & $\begin{array}{l}\text { Membuat gambar/sketsa beserta } \\
\text { keterangan dengan benar yang } \\
\text { relevan dengan permasalahan. }\end{array}$ & TB3 \\
\hline & $\begin{array}{l}\text { Melaksanakan } \\
\text { Rencana } \\
\text { Penyelesaian }\end{array}$ & $\begin{array}{l}\text { Menuliskan langkah-langkah } \\
\text { perhitungan dengan benar yang } \\
\text { relevan dengan permasalahan. }\end{array}$ & TL1 \\
\hline & $\begin{array}{l}\text { Memeriksa } \\
\text { Kembali }\end{array}$ & $\begin{array}{l}\text { Menuliskan kesimpulan dengan } \\
\text { benar sesuai perhitungan. }\end{array}$ & TK1 \\
\hline \multirow{6}{*}{$\underset{\mathrm{n}}{\text { Kelengkapa }}$} & $\begin{array}{l}\text { Memahami } \\
\text { masalah }\end{array}$ & $\begin{array}{l}\text { Menuliskan hal-hal yang diketahui } \\
\text { dan ditanyakan pada soal cukup } \\
\text { untuk menyelesaikan masalah. }\end{array}$ & PM1 \\
\hline & \multirow{3}{*}{$\begin{array}{c}\text { Membuat } \\
\text { Rencana } \\
\text { Penyelesaian }\end{array}$} & $\begin{array}{l}\text { Menuliskan strategi penyelesaian } \\
\text { yang dibutuhkan cukup untuk } \\
\text { menyelesaikan masalah. }\end{array}$ & PB1 \\
\hline & & $\begin{array}{l}\text { Menuliskan istilah/notasi } \\
\text { matematika yang dibutuhkan dalam } \\
\text { penyelesaian soal. }\end{array}$ & PB2 \\
\hline & & $\begin{array}{l}\text { Membuat gambar/sketsa beserta } \\
\text { semua keterangan yang dibutuhkan } \\
\text { cukup untuk menyelesaikan masalah }\end{array}$ & PB3 \\
\hline & \begin{tabular}{|l} 
Melaksanakan \\
Rencana \\
Penyelesaian
\end{tabular} & $\begin{array}{l}\text { Menuliskan langkah-langkah } \\
\text { perhitungan yang dibutuhkan cukup } \\
\text { untuk menyelesaikan masalah. }\end{array}$ & PL1 \\
\hline & $\begin{array}{l}\text { Memeriksa } \\
\text { Kembali }\end{array}$ & $\begin{array}{l}\text { Menuliskan kesimpulan cukup untuk } \\
\text { menyelesaikan masalah yang relevan } \\
\text { dengan permasalahan. }\end{array}$ & PK1 \\
\hline \multirow{4}{*}{$\begin{array}{c}\text { Kelanca } \\
\text { ran }\end{array}$} & $\begin{array}{l}\text { Memahami } \\
\text { Masalah }\end{array}$ & \multirow{4}{*}{$\begin{array}{l}\text { Menuliskan semua informasi sampai } \\
\text { pada kesimpulan dengan benar } \\
\text { dalam batas waktu yang telah } \\
\text { ditentukan serta tidak ada coretan } \\
\text { koreksian kesalahan dalam } \\
\text { pekerjaan tertulisnya. }\end{array}$} & \multirow[t]{4}{*}{ RM1 } \\
\hline & $\begin{array}{l}\text { Membuat } \\
\text { Rencana } \\
\text { Penyelesaian }\end{array}$ & & \\
\hline & $\begin{array}{l}\text { Melaksanakan } \\
\text { Rencana } \\
\text { Penyelesaian }\end{array}$ & & \\
\hline & $\begin{array}{l}\text { Memeriksa } \\
\text { Kembali }\end{array}$ & & \\
\hline
\end{tabular}

Untuk pengumpulan data, 32 siswa di kelas penelitian diberi tes kemampuan matematika yang berjumlah sebanyak 10 soal esai. Dari 32 siswa tersebut dipilih siswa yang mempunyai kemampuan matematika tinggi yang akan diberi tes GEFT yang terdiri dari dua contoh penyelesaian gambar dan 25 soal gambar kompleks yang dikerjakan siswa dengan durasi yang sudah ditentukan. Berdasarkan hasil nilai soal tes GEFT tersebut, siswa dibedakan menjadi 2 bagian yaitu siswa dengan gaya kognitif FD dan FI. Pada penelitian ini terdapat dua subjek, yaitu satu subjek gaya kognitif FD dan satu subjek gaya kognitif FI. Subjek yang dipilih berdasarkan kemampuan matematika tinggi yang setara atau memperoleh hasil dengan selisih yang tidak terlalu jauh yakni $\leqslant 10$ (rentang nilai 0-100), dan kelamin yang sejenis. Sehingga jika terdapat perbedaan komunikasi matematika disebabkan adanya perbedaan gaya kognitif, bukan karena tingkat kemampuan matematika yang dimiliki setiap subjek dan perbedaan jenis kelamin.

Tahap berikutnya, peneliti menganalisis data yang terdiri dari analisis tes TKM, GEFT, dan TKMT. Analisis 
tes GEFT dilakukan dengan menghitung skor GEFT yang telah dilakukan siswa. Skor maksimal yang dapat diperoleh siswa adalah 18 poin. Apabila siswa memperoleh skor $\leqslant$ 11 dari tes GEFT, maka siswa tersebut termasuk kategori gaya kognitif FD. Sedangkan siswa yang memperoleh skor $>11$, maka siswa tersebut termasuk kategori gaya kognitif FI. Analisis TKM dilakukan dengan menghitung skor sesuai dengan pedoman penskoran yang dibuat. Selanjutnya adalah analisis TKMT yang masing-masing masalah dianalisis berdasarkan indikator komunikasi matematika tulis. Proses komunikasi ini menggunakan soal esai dengan materi persamaan kuadrat. Penggunaan soal esai dapat mempermudah dalam mendeskripsikan profil komunikasi siswa tulis dalam pemecahan suatu masalah matematika langkah pemecahan masalah menurut Polya.

Teknik keabsahan data menggunakan triangulasi metode yang bertujuan agar peneliti dapat melakukan pengecekan ulang hasil penelitian dengan membadingkan sumber data yang diperoleh dengan metode yang sama.

\section{HASIL DAN PEMBAHASAN}

Hasil

Tes kemampuan matematika tentang materi yang sudah dipelajari siswa kelas IX-E dengan batas waktu pengerjaan selama 80 menit secara online. Dari tes kemampuan matematika siswa kelas IX-E diperoleh 5 siswa yang berkemampuan matematika tinggi, 14 siswa berkemampuan matematika sedang, dan 13 siswa berkemampuan matematika rendah.

Pada penelitian ini, selanjutnya dipilih siswa dengan kemampuan matematika tinggi sebanyak 5 siswa yang sudah melakukan TKM dengan jenis kelamin perempuan yang akan diberikan tes GEFT. Siswa dengan kemampuan matematika tinggi selanjutnya diberi tes GEFT sebanyak 25 soal gambar kompleks untuk menggolongkan gaya kognitif FD dan gaya kognitif FI sesuai dengan pedoman penskoran yang sudah dibuat. Adapun hasil tes GEFT yang dilakukan siswa untuk menggolongkan gaya kognitif sebagai berikut.

Tabel 2 Hasil Tes Gaya Kognitif Siswa

\begin{tabular}{|c|c|c|c|c|}
\hline No & Nama & Jenis Kelamin & Skor & Gaya Kognitif \\
\hline 1 & AAA & P & 14 & Field Independent \\
\hline 2 & ES & P & 9 & Field Dependent \\
\hline 3 & NML & P & 8 & Field Dependent \\
\hline 4 & PCI & P & 9 & Field Dependent \\
\hline 5 & SI & P & 9 & Field Dependent \\
\hline
\end{tabular}

Berdasarkan tabel diatas didapat 4 siswa dengan gaya kognitif FD yang berjenis kelamin perempuan dan 1 siswa dengan gaya kognitif FI yang berjenis kelamin perempuan. Subjek pada penelitian ini ialah satu siswa dengan gaya kognitif FD dan satu siswa dengan gaya kognitif FI yang memiliki kemampuan metematika tinggi yang setara dan berkelamin sejenis, maka siswa yang dipilih menjadi subjek penelitian seperti pada tabel berikut.

Tabel 3 Subjek Penelitian

\begin{tabular}{|c|c|c|c|c|c|}
\hline No & Nama & Jenis Kelamin & Skor & Gaya Kognitif & Kode \\
\hline 1 & AAA & P & 14 & Field Independent & SFI \\
\hline 2 & NML & P & 8 & Field Dependent & SFD \\
\hline
\end{tabular}

Pemilihan subjek penelitian berdasarkan hasil tes GEFT yang menunjukkan bahwa subjek AAA memperoleh skor tertinggi, berarti subjek AAA memiliki gaya kognitif FI dan subjek NML memperoleh skor terendah, berarti subjek NML memiliki gaya kognitif FD.

Untuk mengetahui tiga aspek yang dinilai dalam komunikasi matematika tulis siswa pada pemecahan masalah matematika dilakukan analisis data pada masingmasing subjek. Hasil dari tes komunikasi matematika tulis dikodekan, SFI dan SFD menyatakan subjek dengan gaya kognitif FI dan FD. Angka terakhir pada kode menyatakan urutan kegiatan.

a. Analisis Data Hasil Tes Komunikasi Matematika Tulis Siswa dengan Gaya Kognitif FI

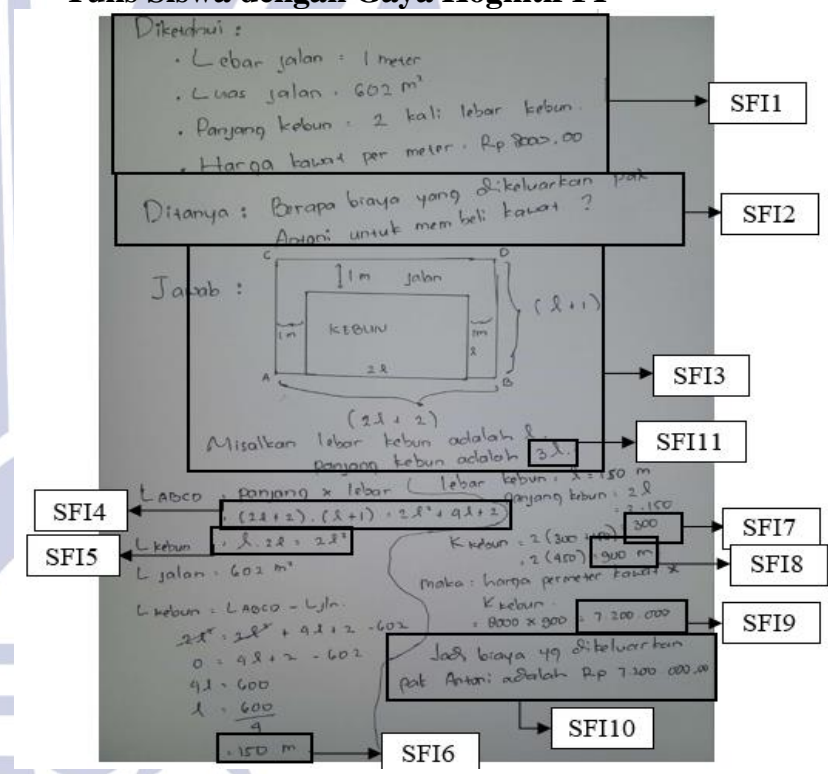

Gambar 1. Hasil Tes Komunikasi Matematika Tulis oleh Subjek SFI

\section{1) Tahap Memahami Masalah}

Berdasarkan gambar 1, analisis komunikasi matematika tulis dalam pemecahan masalah matematika subjek SFI dalam memahami masalah dengan rincian sebagai berikut. a) Keakuratan

Subjek SFI menuliskan hal-hal yang diketahui yang ditunjukkan oleh kode SFI1, informasi yang disampaikan oleh SFI sudah benar yang relevan dengan permasalahan. Subjek SFI juga menuliskan hal-hal yang ditanya yang ditunjukkan oleh kode SFI2 dengan benar yang relevan dengan permasalahan.

b) Kelengkapan

Subjek SFI menuliskan semua hal yang diketahui pada permasalahan dengan lengkap yang ditunjukkan oleh kode SFI1. Selain itu subjek SFI menuliskan semua hal yang 
ditanyakan dengan lengkap yang ditunjukkan oleh kode SFI2.

\section{2) Tahap Membuat Rencana Penyelesaian}

Berdasarkan gambar 1, analisis komunikasi matematika tulis dalam pemecahan masalah matematika subjek SFI dalam membuat rencana penyelesaian dengan rincian sebagai berikut.

a) Keakuratan

Subjek SFI membagi masalah menjadi beberapa sub masalah untuk memperoleh informasi yang belum diketahui untuk menyelesaikan permasalahan. Subjek mencari informasi dengan memodelkan masalah yang diberikan yang ditunjukkan oleh kode SFI3, lebar kebun yang ditunjukkan oleh kode SFI6, panjang kebun yang ditunjukkan oleh kode SFI7, luas persegipanjang $A B C D$ yang ditunjukkan oleh kode SFI4, luas kebun yang ditunjukkan oleh kode SFI5, keliling kebun yang ditunjukkan oleh kode SFI8, dan yang terakhir mencari biaya yang dikeluarkan Pak Antoni yang ditunjukkan oleh kode SFI9. Berdasarkan uraian tersebut menunjukkan bahwa subjek SFI menuliskan strategi penyelesaian masalah dengan benar yang relevan dengan permasalahan pada TKMT karena sesuai dengan langkah penyelesaian masalah yang benar.

Subjek SFI menuliskan istilah/notasi dengan benar, istilah/notasi yang ditulis subjek SFI seperti pada persegipanjang $A B C D$ dan $l$. Istilah/notasi tersebut sudah sesuai dengan kaidah matematika, tetapi pada persegipanjang $A B C D$ tidak diberikan keterangan. Hal tersebut memungkinkan kesalahpahaman makna dari maksud yang sebenarnya. Selain itu, subjek SFI dalam membuat gambar/sketsa yang ditunjukkan oleh kode SFI3 sudah benar sesuai dengan permasalahan pada TKMT.

b) Kelengkapan

Subjek SFI menyelesaikan masalah menggunakan strategi penyelesaian yang belum diketahui dengan mencari informasi lain yang dibutuhkan dalam menyelesaikan soal yaitu lebar kebun adalah 1, panjang kebun adalah 21, lebar persegipanjang besar yang dituliskan dengan notasi $B D$ atau $A C$, dan panjang persegipanjang besar yang dituliskan dengan notasi $A B$ atau $C D$ yang ditunjukkan oleh kode SFI3, luas persegipanjang $A B C D$ yang ditunjukkan oleh kode SFI4, luas kebun yang ditunjukkan oleh kode SFI5, keliling kebun yang ditunjukkan oleh kode SFI8, lebar kebun yang ditunjukkan oleh kode SFI6, panjang kebun yang ditunjukkan oleh kode SFI7, dan biaya yang dikeluarkan Pak Antoni yang ditunjukkan oleh kode SFI9. Berdasarkan penjelasan diatas subjek SFI sudah menuliskan semua informasi strategi penyelesaian yang dibutuhkan dalam menyelesaikan soal.

Subjek SFI menuliskan semua istilah/notasi matematika yang dibutuhkan dalam penyelesaian soal, yaitu istilah/notasi 1 yang menunjukkan lebar kebun, 21 yang menunjukkan panjang kebun, $B D$ atau $A C$ yang menunjukkan lebar persegipanjang besar, $A B$ atau $C D$ yang menunjukkan panjang persegipanjang besar, dan pemberian istilah/notasi panjang dan lebar persegipanjang besar yang terbentuk yaitu dengan istilah/notasi $(2 l+2)$ dan $(l+1)$. Sedangkan dalam membuat gambar/sketsa subjek SFI tidak menuliskan keterangan bahwa $A B C D$ adalah berbentuk persegipanjang.

\section{3) Tahap Melaksanakan Rencana Penyelesaian}

Berdasarkan gambar 1, analisis komunikasi matematika tulis dalam pemecahan masalah matematika subjek SFI dalam melaksanakan rencana penyelesaian dengan rincian sebagai berikut.

a) Keakuratan

Subjek SFI menuliskan perhitungan untuk menjawab permasalahan yang ada pada soal. Adapun langkah pertama yang dilakukan adalah menentukan panjang $A B$ dan lebar $B D$ yang ditunjukkan oleh kode SFI3 dan menghasilkan jawaban yang benar. Langkah kedua, subjek SFI mencari luas $A B C D$ yang ditunjukkan oleh kode SFI4 dan menghasilkan jawaban yang benar. Langkah ketiga, subjek SFI mencari luas kebun yang ditunjukkan oleh kode SFI5 dan menghasilkan jawaban yang benar. Langkah keempat, subjek SFI menghitung lebar kebun yang ditunjukkan oleh kode SFI6 dan menghasilkan perhitungan jawaban dengan benar. Langkah kelima, subjek SFI menghitung panjang kebun yang ditunjukkan oleh kode SFI7 dan menghasilkan perhitungan jawaban dengan benar. Langkah keenam, subjek SFI menghitung keliling kebun yang ditunjukkan oleh kode SFI8 dan menghasilkan perhitungan jawaban dengan benar. Langkah ketujuh, subjek SFI menentukan biaya yang dikeluarkan Pak Antoni dengan cara mengalikan harga per meter kawat dengan keliling kebun yang ditunjukkan oleh kode SFI9 dan memberikan perhitungan jawaban yang benar. Subjek SFI sudah menuliskan langkah-langkah perhitungan dengan benar yang relevan dengan permasalahan, karena sesuai dengan informasi lain yang dicari dan menghasilkan jawaban yang benar.

b) Kelengkapan

Subjek SFI menuliskan langkah-langkah perhitungan mulai dari menentukan panjang $A B$ dan lebar $B D$, mencari luas $A B C D$, mencari luas kebun, menghitung lebar kebun, menghitung panjang kebun, menghitung keliling kebun, dan menentukan biaya yang dikeluarkan Pak Antoni yang ditunjukkan oleh kode SFI1-SFI9. Subjek SFI menuliskan semua informasi langkah-langkah dan data yang dibutuhkan untuk menyelesaikan TKMT, sehingga mendapatkan hasil perhitungan jawaban yang benar.

\section{4) Tahap Memeriksa Kembali}

Berdasarkan gambar 1, analisis komunikasi matematika tulis dalam pemecahan masalah matematika subjek SFI dalam memeriksa kembali penyelesaian dengan rincian sebagai berikut.

a) Keakuratan

Subjek SFI menuliskan kesimpulan yang diperoleh dari hasil perhitungannya "Jadi biaya yg dikeluarkan Pak Antoni adalah $R p$ 7.200.000,00 ", kesimpulan yang dituliskan oleh subjek SFI benar sesuai dengan perhitungan.

\section{b) Kelengkapan}

Subjek SFI menuliskan semua kesimpulan untuk menjawab pertanyaan yang ada pada soal yang ditunjukkan oleh kode SFI10. Berdasarkan hal tersebut subjek SFI menuliskan kesimpulan yang sesuai dengan apa yang diminta dan relevan terhadap permasalahan. 
c) Kelancaran

Subjek SFI menuliskan semua informasi yang dibutuhkan untuk menjawab permasalahan pada soal TKMT sampai pada kesimpulan, semua informasi tersebut dilakukan oleh subjek SFI dalam waktu kurang lebih 18 menit dari 25 menit waktu yang diberikan pada instrument penelitian, mulai dari informasi hal-hal yang diketahui, ditanyakan, strategi penyelesaian, istilah/notasi matematika, gambar/sketsa yang dibutuhkan, langkahlangkah penyelesaian, dan kesimpulan. Akan tetapi, ada sedikit kesalahan menulis yang ditunjukkan oleh kode SFI11, namun hal tersebut tidak mempengaruhi hasil pekerjaan subjek SFI yang menunjukkan hasil akhir yang sesuai dengan permasalahan.

b. Analisis Data Hasil Tes Komunikasi Matematika Tulis Siswa dengan Gaya Kognitif FD

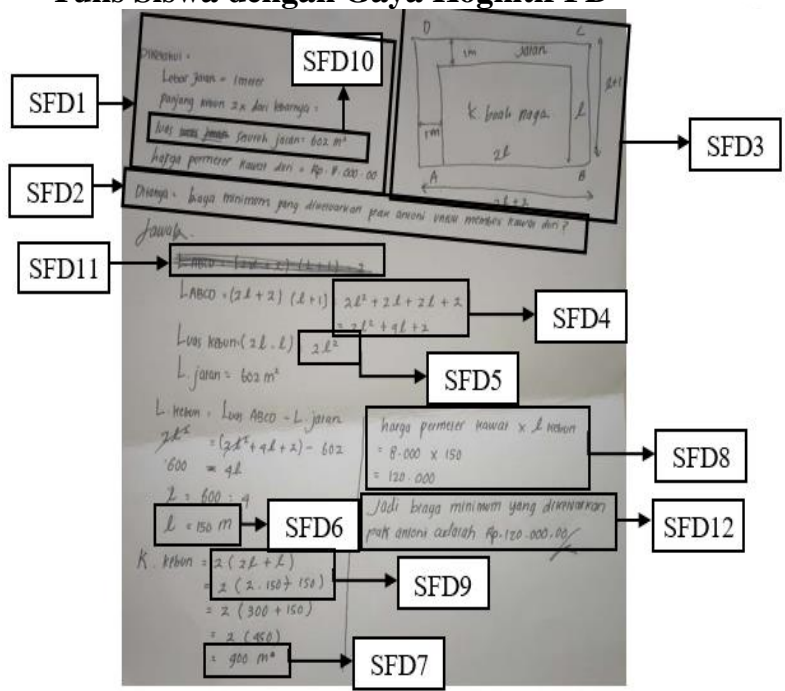

Gambar 2. Hasil Tes Komunikasi Matematika Tulis oleh Subjek SFD

\section{1) Tahap Memahami Masalah}

Berdasarkan gambar 2, analisis komunikasi matematika tulis dalam pemecahan masalah matematika subjek SFD dalam memahami masalah dengan rincian sebagai berikut.

a) Keakuratan

Subjek SFD menuliskan hal-hal yang diketahui yang ditunjukkan oleh kode SFD1, informasi yang disampaikan oleh SFD sudah benar yang relevan dengan permasalahan. Subjek SFD juga menuliskan hal-hal yang ditanya yang ditunjukkan oleh kode SFD2 dengan benar yang relevan dengan permasalahan.

b) Kelengkapan

Subjek SFD menuliskan semua hal yang diketahui pada permasalahan dengan lengkap yang ditunjukkan oleh kode SFD1. Selain itu subjek SFD menuliskan semua hal yang ditanyakan dengan lengkap yang ditunjukkan oleh kode SFD2.

\section{2) Tahap Membuat Rencana Penyelesaian}

Berdasarkan gambar 2, analisis komunikasi matematika tulis dalam pemecahan masalah matematika subjek SFD dalam membuat rencana penyelesaian dengan rincian sebagai berikut.

a) Keakuratan
Subjek SFD membagi masalah menjadi beberapa sub masalah untuk mendapatkan informasi yang belum diketahui dalam menyelesaikan masalah pada TKMT. Informasi yang subjek cari adalah memodelkan masalah yang diberikan yang ditunjukkan oleh kode SFD3, lebar kebun yang ditunjukkan oleh kode SFD6, luas persegipanjang $A B C D$ yang ditunjukkan oleh kode SFD4, luas kebun yang ditunjukkan oleh kode SFD5, keliling kebun yang ditunjukkan oleh kode SFD7, dan yang terakhir mencari biaya minimum yang dikeluarkan Pak Antoni yang ditunjukkan oleh kode SFD8. Subjek SFD menuliskan strategi penyelesaian menjadi beberapa sub masalah dengan kurang benar karena subjek SFD menggunakan strategi yang tidak mengarah pada langkah penyelesaian masalah dengan benar, subjek SFD mencari biaya minimum tidak dengan mengalikan harga permeter kawat duri dengan keliling kebun yang ditunjukkan oleh kode SFD8.

Subjek SFD menuliskan istilah/notasi dengan benar, istilah/notasi yang ditulis subjek SFD seperti pada persegipanjang $A B C D$ dan $l$. Istilah/notasi tersebut sudah sesuai dengan kaidah matematika, tetapi pada persegipanjang $A B C D$ tidak diberikan keterangan. Hal tersebut memungkinkan kesalahpahaman makna dari maksud yang sebenarnya. Selain itu, subjek SFD dalam membuat gambar/sketsa yang ditunjukkan oleh kode SFD3 sudah benar walaupun ukuran gambaran tidak proporsional namun keterangan yang diberikan sesuai dengan permasalahan pada TKMT.

b) Kelengkapan

Subjek SFD menyelesaikan masalah menggunakan strategi penyelesaian yang belum diketahui dengan mencari informasi lain yang dibutuhkan dalam menyelesaikan soal yaitu lebar kebun adalah $l$, panjang kebun adalah $2 l$, lebar persegipanjang besar yang dituliskan dengan notasi $B C$ atau $A D$, dan panjang persegipanjang besar yang dituliskan dengan notasi $A B$ atau $C D$ yang ditunjukkan oleh kode SFD3, luas persegipanjang $A B C D$ yang ditunjukkan oleh kode SFD4, luas kebun yang ditunjukkan oleh kode SFD5, keliling kebun yang ditunjukkan oleh kode SFD7, lebar kebun yang ditunjukkan oleh kode SFD6, dan biaya minimum yang dikeluarkan Pak Antoni untuk membeli kawat duri yang ditunjukkan oleh kode SFD8. Hal tersebut menunjukkan bahwa subjek/SFD tidak menuliskan panjang kebun, tetapi hal tersebut tidak mempengaruhi langkah selanjutnya karena subjek SFD memasukkan nilai dari $2(2 l+l)$ untuk mencari keliling kebun yang ditunjukkan oleh kode SFD9.

Subjek SFD menuliskan semua istilah/notasi matematika yang dibutuhkan dalam penyelesaian soal, yaitu istilah/notasi $l$ yang menunjukkan lebar kebun, $2 l$ yang menunjukkan panjang kebun, $B C$ atau $A D$ yang menunjukkan lebar persegipanjang besar, $A B$ atau $C D$ yang menunjukkan panjang persegipanjang besar, dan pemberian istilah/notasi panjang dan lebar persegipanjang besar yang terbentuk yaitu dengan istilah/notasi $(2 l+2)$ dan $(l+1)$. Sedangkan dalam membuat gambar/sketsa subjek SFD tidak menuliskan keterangan bahwa $A B C D$ adalah berbentuk persegipanjang. 


\section{3) Tahap Melaksanakan Rencana Penyelesaian}

Berdasarkan gambar 2, analisis komunikasi matematika tulis dalam pemecahan masalah matematika subjek SFD dalam melaksanakan rencana penyelesaian dengan rincian sebagai berikut.

a) Keakuratan

Subjek SFD menuliskan perhitungan untuk menjawab permasalahan yang ada pada soal. Adapun langkah pertama yang dilakukan adalah menentukan panjang $A B$ dan lebar $B C$ yang ditunjukkan oleh kode SFD3 dan menghasilkan jawaban yang benar. Langkah kedua, subjek SFD mencari luas $A B C D$ yang ditunjukkan oleh kode SFD4 dan menghasilkan jawaban yang benar. Langkah ketiga, subjek SFD mencari luas kebun yang ditunjukkan oleh kode SFD5 dan menghasilkan jawaban yang benar. Langkah keempat, subjek SFD menghitung lebar kebun yang ditunjukkan oleh kode SFD6 dan menghasilkan perhitungan jawaban dengan benar. Langkah kelima, subjek SFD menghitung keliling kebun dengan cara memasukkan nilai $2 l$ dengan $l$ ke dalam rumus keliling kebun yang ditunjukkan oleh kode SFD7 dan menghasilkan perhitungan jawaban dengan benar. Langkah keenam, subjek SFD menentukan biaya minimum yang dikeluarkan Pak Antoni untuk membeli kawat duri yang ditunjukkan oleh kode SFD8 dan memberikan perhitungan jawaban yang kurang benar karena subjek SFD menentukan biaya minimum dengan cara mengalikan harga per meter kawat dengan $l$ kebun. Subjek SFD menuliskan langkah-langkah perhitungan dengan kurang benar karena ada langkah perhitungan yang kurang tepat.

b) Kelengkapan

Subjek SFD menuliskan langkah-langkah perhitungan mulai dari menentukan panjang $A B$ dan lebar $B C$, mencari luas $A B C D$, mencari luas kebun, menghitung lebar kebun, menghitung keliling kebun, dan menentukan biaya minimum yang dikeluarkan Pak Antoni untuk membeli kawat duri yang ditunjukkan oleh kode SFD3-SFD9. Subjek SFD cukup dalam menuliskan langkah-langkah penyelesaian masalah pada TKMT.

\section{4) Tahap Memeriksa Kembali}

Berdasarkan gambar 2, analisis komunikasi matematika tulis dalam pemecahan masalah matematika subjek SFD dalam memeriksa kembali penyelesaian dengan rincian sebagai berikut.

a) Keakuratan

Subjek SFD menuliskan kesimpulan yang diperoleh dari hasil perhitungannya " Jadi biaya minimum yang dikeluarkan Pak Antoni adalah Rp 120.000,00" yang ditunjukkan oleh kode SFD12, kesimpulan yang dituliskan oleh subjek SFD kurang benar, karena untuk mencari biaya minimum tidak dengan cara mengalikan harga per meter kawat duri dengan keliling kebun.

b) Kelengkapan

Kesimpulan yang ditulis SFD tidak cukup untuk menyelesaikan masalah pada TKMT, yaitu biaya minimum yang dikeluarkan Pak Antoni untuk membeli kawat duri yang dituliskan oleh subjek SFD tidak menjawab pertanyaan pada TKMT yang ditunjukkan oleh kode SFD12. Berdasarkan uraian tersebut, subjek SFD menuliskan kesimpulan tetapi tidak menjawab pertanyaan pada TKMT dan tidak relevan dengan permasalahan.

c) Kelancaran

Subjek SFD menuliskan informasi yang dibutuhkan untuk menjawab permasalahan pada soal TKMT sampai pada kesimpulan, informasi tersebut dilakukan oleh subjek SFD dalam waktu kurang lebih 19 menit dari 25 menit sesuai dengan aturan pada istrumen penelitian, mulai dari informasi hal-hal yang diketahui, ditanyakan, strategi penyelesaian, istilah/notasi matematika, gambar/sketsa yang dibutuhkan, langkah-langkah penyelesaian, dan kesimpulan. Akan tetapi, ada sedikit coretan yang ditunjukkan oleh kode SFD10 dan SFD11. Hal tersebut tidak mempengaruhi hasil pekerjaan subjek SFD tetapi menunjukkan hasil akhir yang kurang sesuai dengan permasalahan pada TKMT

\section{Pembahasan}

Berdasarkan hasil dan analisis data tes komunikasi matematika tulis siswa, diperoleh profil komunikasi matematika tulis siswa dalam pemecahan masalah matematika berdasarkan gaya kognitif FI dan FD yaitu sebagai berikut.

1. Profil Komunikasi Matematika Tulis Siswa dalam Pemecahan Masalah Matematika dengan Gaya Kognitif FI.

Pembahasan tentang komunikasi matematika tulis subjek SFI dalam pemecahan masalah sebagai berikut.

a. Memahami Masalah

Subjek SFI menuliskan hal-hal yang diketahui dan ditanya dengan benar yang relevan dengan permasalahan dan tidak ada koreksian kesalahan dalam pengerjaannya. Sehingga subjek SFI dapat dikatakan akurat, lengkap, dan lancar dalam menuliskan hal-hal yang diketahui dan ditanya. Hal ini sejalan dengan pendapat Achir, dkk (2017) bahwa siswa dengan gaya kognitif FI dapat menuliskan hal-hal yang diketahui dan ditanyakan pada TKMT dengan tepat.

b. Membuat Rencana Penyelesaian

Subjek SFI mencari informasi yang belum diketahui dengan membuat strategi penyelesaian menjadi beberapa sub masalah dengan benar yang relevan dengan permasalahan. Selain itu, subjek SFI menggunakan strategi penyelesaian masalah dengan benar dan cukup untuk menyelesaikan masalah serta tidak ada koreksian kesalahan dalam pengerjaannya, sehingga subjek SFI dapat dikatakan akurat, lengkap, dan lancar. Sejalan dengan hal tersebut, Wulan \& Anggraini (2019) menyatakan bahwa siswa dengan gaya kognitif FI dalam merencanakan dan melakukan aktivitas yang mengarah pada penyelesaian masalah dengan benar. Hal ini dikarenakan siswa dengan gaya kognitif FI mampu mengorganisasikan informasi secara mandiri sehingga mampu melakukan tindakan yang mengarah pada solusi yang benar (Tisngati, 2015)

Dalam menyelesaikan soal subjek SFI menuliskan istilah/notasi yang dibutuhkan dengan benar yang sesuai dalam kaidah matematika dan tidak ada koreksian kesalahan dalam pengerjaannya. Selain itu, subjek SFI juga membuat sketsa/gambar segi empat dengan benar walaupun tidak ada keterangan segi empat apa yang terbentuk, namun sudah cukup untuk menyelesaikan 
masalah serta tidak ada koreksian kesalahan dalam pengerjaannya. Sehingga subjek SFI dapat dikatakan akurat, lengkap, dan lancar dalam menuliskan istilah/notasi dan membuat gambar/sketsa.

c. Melaksanakan Rencana Penyelesaian

Subjek SFI menuliskan langkah-langkah penyelesaian dan perhitungan dengan benar dan cukup yang relevan dengan permasalahan serta tidak ada koreksian kesalahan dalam pengerjaannya. Sehingga subjek SFI dapat dikatakan akurat, lengkap, dan lancar dalam menuliskan langkahlangkah perhitungan. Hal ini sejalan dengan pendapat Achir, dkk (2017) bahwa subjek dengan gaya kognitif FI mampu melaksanakan langkah-langkah perhitungan dengan tepat dan sistematis.

d. Memeriksa Kembali

Subjek SFI menuliskan kesimpulan yang didapat dari hasil perhitungan yang sudah dilakukan selama 18 menit untuk menyelesaikan masalah yang relevan pada TKMT. Meskipun ada sedikit kesalahan menulis, namun hal tersebut tidak mempengaruhi hasil pekerjaan subjek SFI yang menunjukkan hasil akhir yang sesuai dengan permasalahan, sehingga subjek SFI dapat dikatakan akurat, lengkap, dan lancar.

2. Profil Komunikasi Matematika Tulis Siswa dalam Pemecahan Masalah Matematika dengan Gaya Kognitif FD

Pembahasan tentang komunikasi matematika tulis subjek SFD dalam pemecahan masalah sebagai berikut.

a. Memahami Masalah

Subjek SFD menuliskan semua hal yang diketahui dan ditanya dengan benar yang relevan dengan permasalahan padaTKMT, sehingga subjek SFD dapat dikatakan akurat dan lengkap. Tetapi dalam menuliskan hal-hal yang diketahui terdapat coretan koreksian, sehingga subjek SFD dikatakan tidak lancar.

b. Membuat Rencana Penyelesaian

Subjek SFD mencari informasi yang belum diketahui dengan membuat strategi penyelesaian menjadi beberapa sub masalah dengan kurang benar karena strategi yang digunakan tidak mengarah pada langkah penyelesaian masalah yang benar. Hal ini disebabkan karena subjek SFD menerima informasi secara keseluruhan atau global sehingga kurang mampu dalam mengorganisasikan informasi dengan mandiri dan kurang benar dalam menggunakan solusi (Haryanti \& Masriyah, 2018). Sehingga subjek SFD dikatakan tidak akurat dalam menuliskan strategi penyelesaian masalah. Selain itu, dalam menuliskan strategi penyelesaian subjek SFD dikatakan tidak lengkap dan tidak lancar karena ada informasi yang tidak dituliskan oleh subjek SFD dan ada coretan koreksian kesalahan.

Dalam menyelesaikan soal subjek SFD menuliskan istilah/notasi yang dibutuhkan dengan benar yang sesuai dalam kaidah matematika dan tidak ada koreksian kesalahan dalam pengerjaannya. Selain itu, subjek SFD juga membuat sketsa/gambar segi empat dengan benar walaupun tidak membuat dengan ukuran proposional dan tidak ada keterangan segi empat apa yang terbentuk, namun sudah cukup untuk menyelesaikan masalah serta tidak ada koreksian kesalahan dalam pengerjaannya. Sehingga subjek SFD dapat dikatakan akurat, lengkap, dan lancar dalam menuliskan istilah/notasi dan membuat gambar/sketsa.

c. Melaksanakan Rencana Penyelesaian

Subjek SFD menuliskan langkah-langkah penyelesaian dengan kurang benar karena terdapat langkah perhitungan yang dituliskan subjek SFD kurang tepat, sehingga subjek SFD dapat dikatakan tidak akurat. Tetapi langkah-langkah yang ditulis oleh subjek SFD sudah cukup untuk menyelesaikan masalah, sehingga dapat dikatakan lengkap. Pada langkah melaksanakan rencana penyelesaian ini subjek SFD menuliskan langkah-langkah perhitungan dengan ada coretan koreksian, sehingga dapat dikatakan tidak lancar.

d. Memeriksa Kembali

Subjek SFD menuliskan kesimpulan yang diperoleh dari hasil perhitungan yang telah dilakukan dengan kurang benar dan tidak relevan dengan permasalahan, sehingga subjek SFD dapat dikatakan tidak akurat, tidak lengkap, dan tidak lancar.

Tabel 4 Rekapitulasi Profil Komunikasi Matematika Tulis Siswa dalam Pemecahan Masalah Matematika Berdasarkan Gaya Kognitif FD dan FI

\begin{tabular}{|c|c|c|}
\hline \multirow{2}{*}{$\begin{array}{c}\text { Kode } \\
\text { Indikator }\end{array}$} & \multicolumn{2}{|r|}{ Subjek } \\
\hline & SFI & SFD \\
\hline TM1 & $\begin{array}{l}\text { Subjek SFI menuliskan } \\
\text { hal-hal yang diketahui } \\
\text { serta ditanyakan secara } \\
\text { akurat. }\end{array}$ & $\begin{array}{l}\text { Subjek SFD menuliskan hal-hal } \\
\text { yang diketahui serta ditanyakan } \\
\text { secara akurat. }\end{array}$ \\
\hline TB1 & $\begin{array}{l}\text { Subjek SFI menuliskan } \\
\text { strategi pemecahan } \\
\text { masalah secara akurat. }\end{array}$ & $\begin{array}{l}\text { Subjek SFD dalam menuliskan } \\
\text { strategi penyelesian dikatakan } \\
\text { tidak akurat karena tidak } \\
\text { mengarah pada langkah } \\
\text { penyelesaian masalah dengan } \\
\text { benar. }\end{array}$ \\
\hline TB2 & $\begin{array}{l}\text { Subjek SFI menuliskan } \\
\text { istilah/notasi secara } \\
\text { akurat. }\end{array}$ & $\begin{array}{l}\text { Subjek SFD menuliskan } \\
\text { istilah/notasi secara akurat. }\end{array}$ \\
\hline TB3 & $\begin{array}{l}\text { Subjek SFI membuat } \\
\text { gambar atau sketsa } \\
\text { secara akurat. }\end{array}$ & $\begin{array}{l}\text { Subjek SFD membuat gambar } \\
\text { atau sketsa secara akurat. }\end{array}$ \\
\hline TL1 & $\begin{array}{l}\text { Subjek SFI menuliskan } \\
\text { langkah-langkah } \\
\text { perhitungan dengan } \\
\text { akurat. }\end{array}$ & $\begin{array}{l}\text { Subjek SFD menuliskan } \\
\text { langkah-langkah perhitungan } \\
\text { yang kurang tepat sehingga } \\
\text { dikatakan tidak akurat. }\end{array}$ \\
\hline TK1 & $\begin{array}{l}\text { Subjek SFI menuliskan } \\
\text { kesimpulan secara } \\
\text { akurat. }\end{array}$ & $\begin{array}{l}\text { Subjek SFD menuliskan } \\
\text { kesimpulan yang kurang benar } \\
\text { sehingga dikatakan tidak } \\
\text { akurat. }\end{array}$ \\
\hline PM1 & $\begin{array}{l}\text { Subjek SFI menuliskan } \\
\text { hal-hal yang diketahui } \\
\text { serta ditanyakan secara } \\
\text { lengkap. }\end{array}$ & $\begin{array}{l}\text { Subjek SFD menuliskan hal-hal } \\
\text { yang diketahui serta ditanyakan } \\
\text { secara lengkap. }\end{array}$ \\
\hline PB1 & \begin{tabular}{lr}
\multicolumn{2}{l}{ Subjek SFI menuliskan } \\
strategi & pemecahan \\
masalah & secara \\
lengkap. &
\end{tabular} & $\begin{array}{l}\text { Subjek SFD menuliskan } \\
\text { strategi pemecahan masalah } \\
\text { secara tidak lengkap karena ada } \\
\text { informasi yang tidak dituliskan. }\end{array}$ \\
\hline PB2 & $\begin{array}{l}\text { Subjek SFI menuliskan } \\
\text { istilah notasi secara } \\
\text { lengkap. }\end{array}$ & $\begin{array}{l}\text { Subjek SFD menuliskan istilah } \\
\text { notasi secara lengkap. }\end{array}$ \\
\hline PB3 & $\begin{array}{l}\text { Subjek SFI membuat } \\
\text { gambar atau sketsa } \\
\text { secara lengkap. }\end{array}$ & $\begin{array}{l}\text { Subjek SFD membuat gambar } \\
\text { atau sketsa secara lengkap. }\end{array}$ \\
\hline PL1 & $\begin{array}{l}\text { Subjek SFI menuliskan } \\
\text { langkah-langkah } \\
\text { perhitungan dengan } \\
\text { lengkap. }\end{array}$ & $\begin{array}{lcc}\text { Subjek SFD } & \text { menuliskan } \\
\text { langkah-langkah } & \text { perhitungan } \\
\text { dengan lengkap. } & \end{array}$ \\
\hline PK1 & $\begin{array}{l}\text { Subjek SFI menuliskan } \\
\text { kesimpulan secara } \\
\text { lengkap. }\end{array}$ & $\begin{array}{l}\text { Subjek SFD menuliskan } \\
\text { kesimpulan tidak lengkap. }\end{array}$ \\
\hline
\end{tabular}




\begin{tabular}{|c|c|c|}
\hline \multirow{2}{*}{$\begin{array}{c}\text { Kode } \\
\text { Indikator }\end{array}$} & \multicolumn{2}{|r|}{ Subjek } \\
\hline & SFI & SFD \\
\hline RM1 & $\begin{array}{lr}\text { Subjek SFI menuliskan } \\
\text { semua informasi } \\
\text { sampai pada } \\
\text { kesimpulan dengan } \\
\text { benar dalam waktu } 18 \\
\text { menit dan tidak ada } \\
\text { koreksian kesalahan } \\
\text { dalam an dalam } \\
\text { pengerjaannya, } \\
\begin{array}{l}\text { sehingga subjek SFI } \\
\text { dikatakan lancar. }\end{array}\end{array}$ & $\begin{array}{l}\text { Subjek SFD menuliskan } \\
\text { kesimpulan yang diperoleh } \\
\text { dengan kurang benar dan tidak } \\
\text { relevan dengan permasalahan } \\
\text { yang dikerjakan dalam waktu } \\
19 \text { menit, sehingga subjek SFD } \\
\text { dikatakan tidak lancar. }\end{array}$ \\
\hline
\end{tabular}

Tabel 5 menunjukkan bahwa terdapat perbedaan antara subjek dengan gaya kognitif FD dan subjek dengan gaya kognitif FI. Hal ini sejalan dengan penelitian Wulan \& Anggraini (2019) bahwa subjek FI mampu melakukan keempat langkah pemecahan masalah menurut Polya dengan baik. Selain itu, penelitian Achir, dkk (2017) menunjukkan hasil yang serupa bahwa siswa dengan gaya kognitif FD memiliki kemampuan komunikasi matematika tulis termasuk dalam kategori rendah-sedang, sedangkan siswa dengan gaya kognitif FI memiliki kemampuan komunikasi matematika tulis termasuk dalam kategori tinggi-sangat tinggi. Oleh karena itu, gaya kognitif mempengaruhi cara seseorang untuk memproses informasi, salah satunya ketika mengomunikasikan ide/gagasan dalam pemecahan masalah matematika.

\section{PENUTUP}

\section{Simpulan}

Simpulan yang didapat dari hasil penelitian dan pembahasan ini yaitu;

1. Profil Komunikasi Matematika Tulis Siswa dalam

Pemecahan Masalah Matematika dengan Gaya

Kognitif FI

Subjek SFI dalam memahami masalah menuliskan halhal yang diketahui serta ditanyakan secara akurat, lengkap, dan lancar. Selanjutnya, subjek SFI membuat rencana penyelesaian dengan menuliskan strategi pemecahan masalah, istilah/notasi, dan membuat gambar atau sketsa secara akurat, lengkap, dan lancar. Dalam tahap melaksanakan rencana penyelesaian, subjek SFI menuliskan tahap-tahap perhitungan dengan akurat, lengkap, dan lancar. Selanjutnya pada tahap memeriksa kembali, kesimpulan dituliskan secara akurat, lengkap, dan lancar oleh subjek SFI.

2. Profil Komunikasi Matematika Tulis Siswa dalam

Pemecahan Masalah Matematika dengan Gaya Kognitif FD

Subjek SFD dalam memahami masalah menuliskan hal-hal yang diketahui serta ditanyakan secara akurat, lengkap, dan tidak lancar. Selanjutnya, subjek SFD membuat rencana penyelesaian dengan menuliskan strategi pemecahan masalah secara tidak akurat, tidak lengkap, dan tidak lancar. Sedangkan dalam menuliskan istilah atau notasi dan membuat gambar atau sketsa secara akurat, lengkap, dan lancar. Dalam tahap melaksanakan rencana penyelesaian, subjek SFD menuliskan tahap-tahap perhitungan dengan tidak akurat, lengkap, dan tidak lancar. Selanjutnya pada tahap memeriksa kembali, kesimpulan dituliskan secara tidak akurat, tidak lengkap, dan tidak lancar oleh subjek SFD.

\section{Saran}

1. Bagi siswa yang memiliki gaya kognitif field dependent, sebaiknya dilakukan bimbingan belajar yang lebih dibandingkan dengan siswa yang memiliki gaya kognitif field independent, karena siswa dengan gaya kognitif field dependent terikat dengan lingkungan dan sulit bekerja secara mandiri.

2. Agar komunikasi matematika tulis siswa lebih optimal, maka sebaiknya guru merancang pembelajaran yang dapat melatih komunikasi matematika tulis siswa, misalnya dengan memberikan soal pemecahan masalah dimana terdapat indikator soal yang menuntut komunikasi tulis siswa.

3. Untuk penelitian selanjutnya, sebaiknya dilakukan penelitian lanjutan tentang profil komunikasi matematika lisan serta perbedaan profil komunikasi matematika tulis dengan lisan, meninjau dari gaya kognitif selain field dependent dan field independent, dan memperluas subjek penelitian.

4. Penelitian ini hanya terbatas pada satu materi yaitu persamaan kuadrat. Oleh karena itu, sebaiknya dilakukan penelitian lanjutan tentang materi lainnya.

5. Penelitian ini hanya menggunakan indikator yang diadaptasi dari penelitian seorang ahli. Untuk penelitian selanjutnya, sebaiknya dilakukan penelitian dengan menggunakan indikator dari beberapa pendapat para ahli.

\section{DAFTAR PUSTAKA}

Achir. S. S., Usodo, B., \& Setiawan, R. 2017. Analisis Kemampuan Komunikasi Matematis Siswa dalam Pemecahan Masalah Matematika Pada Materi Sistem Persamaan Linear Dua Variabel (SPLDV) Ditinjau Dari Gaya Kognitif. Jurnal Penelitian Pendidikan, 1(20). (Online), (https://jurnal.uns.ac.id/paedagogia/article/download/ 16600/pdf), diakses 28 November 2020.

American Education Reaches Out. (2011). Mathematics: Crosswalk AERO and the Common Core, (Online), (http://www.projectaero.org/aero_standards/AEROCommonCore.pdf), diakses 12 Februari 2020.

Arifin, S., A. Rahman \& Asdar. (2015). Profil Pemecahan Masalah Matematika Siswa Ditinjau dari Gaya Kognitif dan Efikasi Diri pada Siswa Kelas VIII Unggulan SMPN 1 Watampone. 3(1): 21

Depdikbud. 2014. PERMENDIKBUD No.58 Th. 2014 tentang Kurikulum 2013 Sekolah Menengah Perrtama/Madrasah Tsanawiyah. (Online). Tersedia: 
http://staff.unila.ac.id/ngademunhd/files/2012/03/Per men-58-ttg-Kurikulum-SMP.doc. Diakses 10 Februari 2020.

Depdikbud. 2016. Permendikbud Nomor 21 Tahun 2016 tentang Standar Isi Pendidikan Dasar dan Menengah. Jakarta: Depdikbud.

Dewi, Izwita. 2009. Profil Komunikasi Matematika Mahasiswa Calon Guru Ditinjau dari Perbedaan Jenis Kelamin. Disertasi tidak dipublikasikan pasca sarjana Universitas Negeri Surabaya.

Haryanti, C. F. \& Masriyah. 2018. Profil Penalaran Matematika Siswa SMP dalam Memecahkan Masalah Open Ended Ditinjau dari Gaya Kognitif Field Dependent dan Field Independent. MATHEdunesa, $7(2)$. (Online), (https://jurnalmahasiswa.unesa.ac.id/index.php/mathe dunesa/article/viewFile/23480/21465), diakses 01 Desember 2020.

Hudojo, H. 2005. Pengembangan Kurikulum dan Pembelajaran Matematika. Malang: UM Press.

Isroil, A., Budayasa, I. K., \& Masriyah. (2017). Profil Berpikir Siswa SMP dalam Menyelesaikan Masalah Matematika Ditinjau dari Kemampuan Matematika. Jurnal Review Pembelajaran Matematika, 2(2). (Online),(http://jurnalftk.uinsby.ac.id/index.php/jrpm/ article/view/47), diakses 02 November 2020.

Mahmudi, Ali. 2009. "Komunikasi dalam Pembelajaran Matematika". Makalah Termuat pada Jurnal MIPMIPA UNHALU. Vol. 8 No. 1.

Margarani, R. \& Ismail. 2016. Profil Kemampuan Komunikasi Matematika Siswa dalam Pemecahan Masalah Matematika Ditinjau dari Gaya Kognitif Reflektif-Impulsif. Jurnal Volume 3 No. 5 Tahun 2016, ISSN: 2301-9085.j

Martini, Dwi. 2015. Profil Kemampuan Komunikasi Matematika Siswa SD Dalam Menyelesaikan Masalah Matematika Ditinjau Dari Gaya Kognitif Field Dependent Dan Field Independent. Tesis Tidak Dipublikasikan. Surabaya: Universitas Negeri Surabaya.

NCTM. 2000. Principles and Standarts for School Mathematics. Reston: Virginia.

NYS Board. 2005. Mathematics core curriculum MST Standard 3 Prekinddergarten-Grade 12 Revised March 2005. New York: University of The State of New York.

Polya, G. 1973. How to Solve It, A New Aspect for Mathematical Method. New Jersey: Princceton University Press.

Rahyubi, Heri. (2012). Teori-teori Belajar dan Aplikasi Pembelajaran Motorik. Bandung: Nusa Media.

Ritonga, S. N. (2018). Analisis Kemampuan Komunikasi Matematis Siswa dalam Pembelajaran Matematika MTs Hifzil Qur'an Medan Tahun 2017/2018. Online].
Tersedia:

http://repository.uinsu.ac.id/3987/1/Word\%20Skripsi \%20Siti\%20Nurcahyani\%20Ritonga.pdf. Diakses 13 Desember 2020.

Rostampour, M. \& Niroomand, S. (2014). Field dependence/independence cognitive styles: Are they significant at different levels of vocabulary knowledge? International Journal of Education and Literacy Studies, 2(1), 52-57.

Satriawati, Gusni "Pembelajaran Matematika dengan Pendekatan Open-ended untuk Meningkatkan Pemahaman dan Kemampuan Komunikasi Matematik Siswa SMP", dalam Jurnal Matematika dan Pendidikan Matematika, vol. 1, th 2006, h. 109.

Siswono, T. Y. E. 2008. Model Pembelajaran Matematika Berbasis Pengajuan dan Pemecahan Masalah Untuk Meningkatkan Kemampuan Berpikir Kreatif. Surabaya: Unesa University Press.

Susan, H. \& Collinson, G. 2005. Achieving EvidenceBased Practices A Handbook for Practitioners. Second Edition. Elsevier.

Tisngati, U. 2015. Proses Berpikir Reflektif Mahasiswa dalam Pemecahan Masalah pada Materi Himpunan Ditinjau dari Gaya Kognitif Berdasarkan Langkah Polya, 8(2). (Online), (https://jurnalbeta.ac.id/index.php/betaJTM/article/do wnload/29/22/), diakses 27 November 2020.

Uno, H. B. 2008. Orientasi Baru Dalam Psikologi Pembelajaran. Jakarta: PT. Bumi Aksara.

Witkin, H. A, Moore, C. A. Goodenough, D. R. and Cox, P. W. Field Dependent and Field Independent Cognitive Styles and Their Educational Impilcations. Review of American Education Research Journal. Vol 47 no 1, tahun 1997. Hal 39.

Wooldridge, B. \& Bartolf, M. (2006). The Field Dependence/Field Indipendence learning Style: im]plications for Adult Student Diversity, Outcomes Assesment AND Accountability. Editor: R. R. Sims and S. J. Sims, pp.237-257. Nova Science Publish, Inc. New York.

Wulan, E. R. \& Anggraini. R. E. 2019. Gaya Kognitif Field-Dependent dan Field-Independent sebagai Jendela Profil Pemecahan Masalah Polya dari Siswa SMP, Focus ACTion Of Research Mathematic 2(1). (Online),(https://www.jurnal.iainkediri.ac.id/index.ph $\mathrm{p} /$ factorm/article/download/1503/824), diakses 01 Desember 2020) 